\title{
Retraction Note to: Corrosion protection of steel sheets by chitosan from shrimp shells at acid pH
}

\author{
Ubong M. Eduok $\cdot$ Mazen M. Khaled
}

Published online: 21 October 2014

(C) Springer Science+Business Media Dordrecht 2014

Retraction Note to: Cellulose (2014) 21:3139-3143 DOI 10.1007/s10570-0140384-2

The article DOI 10.1007/s10570-014-0384-2 has been retracted. The authors requested the retraction as the article was submitted to the journal in error without the prior consent or agreement of Mazen M. Khaled. The Publisher and Editor have agreed to retract the article after receiving a written explanation of the situation.

The online version of the original article can be found under doi:10.1007/s10570-014-0384-2.

U. M. Eduok $(\varangle) \cdot$ M. M. Khaled Department of Chemistry, King Fahd University of Petroleum and Minerals, Dhahran 31261, Saudi Arabia e-mail: ublook@yahoo.com 